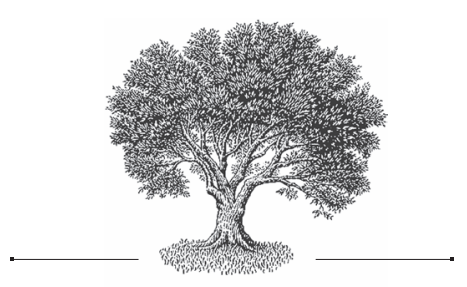

\section{О двух древнерусских надписях из Белоруссии и Польши}

\section{Савва Михайдович Михеев}

Институт славяноведения РАН (Москва)

\title{
On Two Old Russian Inscriptions from Belarus and Poland
}

\section{Savva M. Mikheev}

Institute for Slavic Studies of the Russian Academy of Sciences (Moscow)

\section{Резюме}

В данной заметке рассматриваются два древнерусских граффити: надпись Марькова жана добра 'Маркова жена - добрая / хорошая' конца ХІІІ или начала XIV века со стены Спасо-Преображенской церкви Спасо-Евфросиниевского монастыря в Полоцке и надпись Ежьковг ножь а иже и жкрадеть прожл.тог ... 'Ежков нож. А кто его украдет, проклят . . .' конца XI - XII века на костяной рукояти ножа, происходящей из раскопок в Дрохичине (древнерусском Дорогычине) на востоке Польши. Обе надписи уже публиковались ранее, однако их прочтение требует нескольких уточнений, а их палеография и язык - более обстоятельного комментария. Как показано в заметке, полоцкая надпись, интересная своей восхваляющей формулой, содержит ранний пример отражения яканья, белорусской фонетической особенности. Дрогичинская же надпись выделяется весьма нестандартной палеографией.

\section{Ключевые слова}

Белоруссия, Полоцк, Спасо-Евфросиниевский монастырь, Спасо-Преображенская церковь, Польша, Дрохичин (Дрогичин), археология, эпиграфика, надписи-граффити, палеография, древнерусский язык, история белорусского языка, XI-XIV века 


\section{Abstract}

Two Old Russian graffiti inscriptions are examined in the present paper. The first one, dating back to the late 13th-early 14th centuries, is located on one of the walls of the Savior Transfiguration Church in the St. Euphrosyne convent in Polotsk, Belarus. It reads Marbkova žana dobra 'Mark's wife is good.' The second graffito was inscribed on a knife handle excavated in Drohiczyn, Eastern Poland (Old Russian Dorogyčinz), and dates to the end of the 11th through the 12th centuries. The inscription reads Ežbkovъ nožb a iže i ukradets proklętı . . ' Ezhko's knife. Whoever steals it, be cursed...' Although both inscriptions have been published, the present study adds more in-depth paleographic and linguistic commentary and suggests corrected readings. The laudatory inscription from Polotsk is particularly interesting because it contains an early example of a spelling reflecting yakanye, a trait of Belarusian phonetics, whereas the interest of the Drohiczyn inscription lies in its unusual paleographic features.

\section{Keywords}

Belarus, Polotsk, St. Euphrosyne convent, Transfiguration Church, Poland, Drohiczyn, archaeology, epigraphy, graffiti inscriptions, paleography, Old Russian, Belarusian language history, 11th-14th centuries

Мой интерес к двум древнерусским надписям-граффити, о которых пойдет речь ниже, был вызван прочтением книги “матери белорусской эпиграфики” Инны Леонидовны Калечиц “Эпіграфіка Беларусі XXIV стст.” [КАлЕчыц 2011]. Эта заметка посвящается бабушке и двоюродной бабушке белорусской эпиграфики - Татьяне и Милене Всеволодовнам Рождественским. Хочется надеяться, что формализованность подачи материала будет скрашена нестандартностью текстов рассматриваемых надписей.

\section{"Маркова жена" из Полоцка}

Я сердечно признателен И. Л. Калечиц за предоставленные ею фотографии заинтересовавшего меня полоцкого граффито.

Местоположение: Полоцк, Спасо-Евфросиньев монастырь, СпасоПреображенская церковь, проем между алтарем и жертвенником (согласно [КАЛЕчЫЦ 2011: 147]).

Материал: Фресковая штукатурка, датирующаяся началом 1160-х ГодОВ [САРАБЬЯНОВ 2012: 286-330].

Тип надписи: Граффито.

Сохранность: Поверх надписи пришлось несколько штрихов более поздних граффити. 

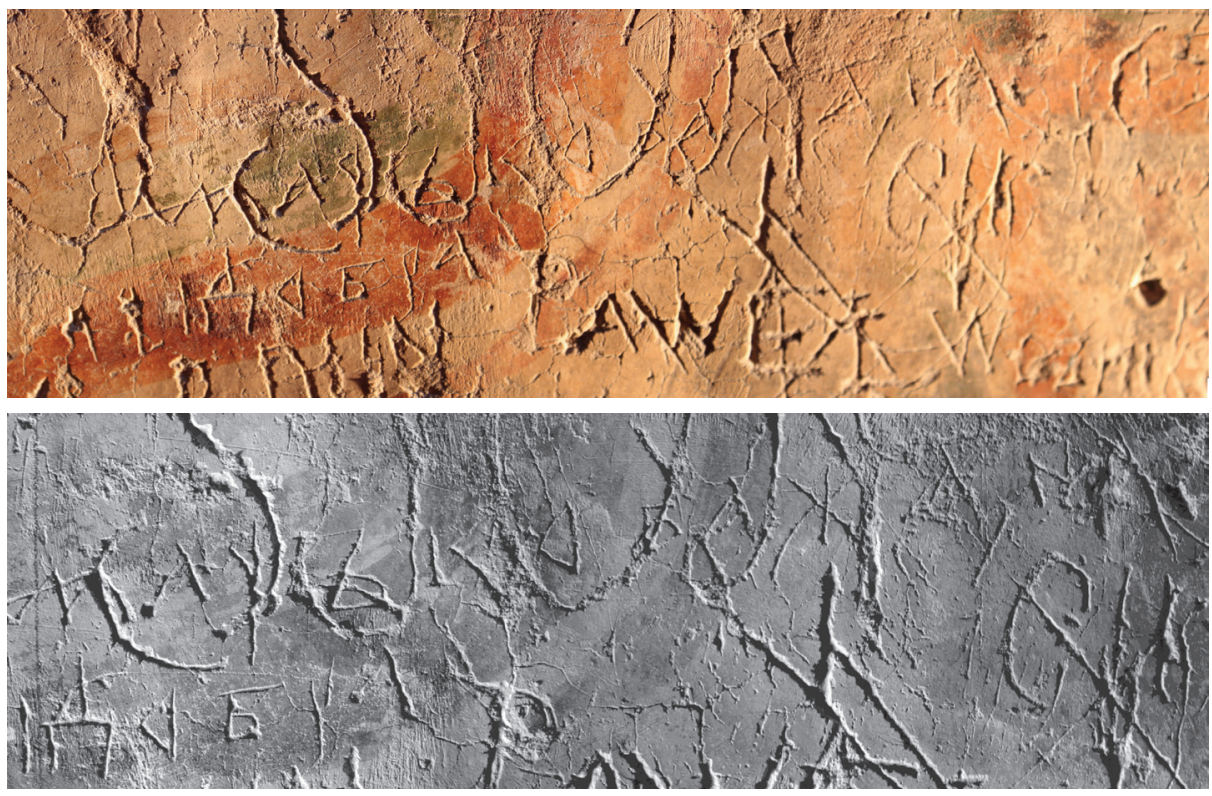

Pис. 1. Стена Спасо-Преображенской церкви. Фотография, предоставленная И. Л. Калечиц (сверху) ${ }^{1}$, фотография И. Л. Калечиц (внизу)

Fig. 1. Wall of the Transfiguration Church. Photograph provided by I. L. Kalechits (top), photograph by I. L Kalechits (bottom)

Текст:

$$
\begin{aligned}
& 1 \text { Маръкова жана } \\
& 2 \text { добра }
\end{aligned}
$$

Лингвистический разбор:

Нормализация:

Грамматическая характеристика: Словарная форма:

Перевод:

$\begin{array}{lll}\text { Маргкова } & \text { жана| } & \text { добра } \\ \text { Маркова } & \text { жена } & \text { добра } \\ \text { NOM.SG.F } & \text { NOM.SG } & \text { NOM.SG.F } \\ \text { Марковъ } & \text { жена } & \text { добръ } \\ \text { 'Маркова } & \text { жена - } & \text { добрая / хорошая'. }\end{array}$

Издания: (фотография, прорись) КАЛЕчыц 2011: 147, 254 (фот. 147, рыс. 195), № $116^{2}$.

Литература: КАЛЕчИЦ 2013: $144^{3}$.

1 Данная фотография приведена в книге И. Л. Калечиц в черно-белой передаче [КАлЕчЫЦ 2011: 254 (фот. 147)]. См. увеличенную центральную часть этой фотографии на рис. 2 ниже.

2 Первоначально И. Л. Калечиц не имела доступа в алтарную часть церкви, поэтому надпись опубликована ею по фотографии, выполненной помощником (письма И. Л. Калечиц автору от 14 и 27 апреля 2014 года).

3 В новейшем издании части граффити Спасо-Преображенской церкви [ЗАлилов 2014] рассматриваемая надпись не упоминается. 

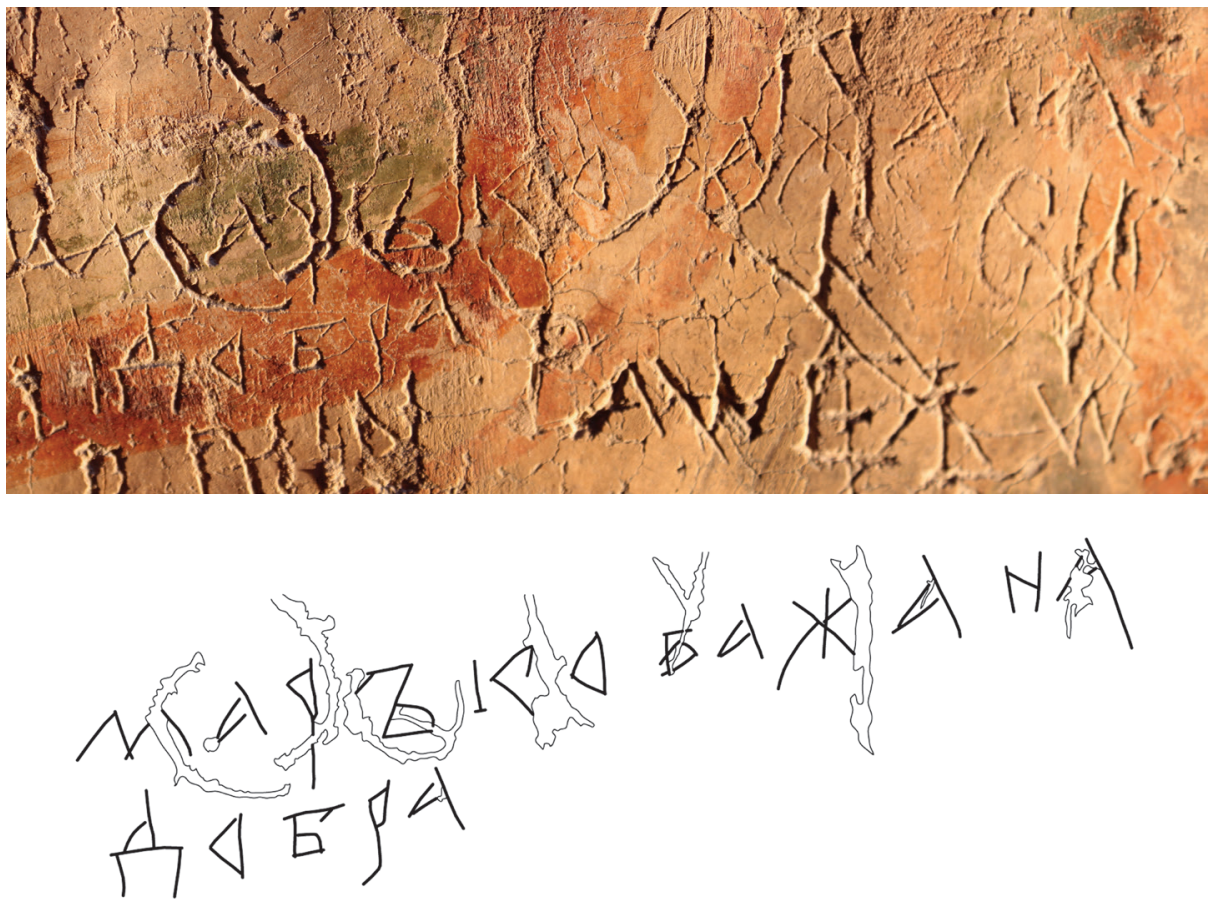

Рис. 2. Полоцкая надпись. Фотография, предоставленная И. Л. Калечиц (увеличена), прорись автора

Fig. 2. Inscription from Polotsk. Photograph provided by I. L. Kalechits (enlarged), line drawing of the author

Датировка: По мнению И. Л. Калечиц, надпись относится к рубежу XIII-XIV веков. По методике внестратиграфического датирования А.А. ЗАлизнякА [2000] граффито следует отнести ориентировочно к первому двадцатилетию XIV века4

Комментарий: В книге И. Л. Калечиц первая строка воспроизведена неверно из-за ошибок в прочтении букв $p, 8, \ldots$ и на и в словоделении.

В написании жана <жена> отражается яканье в первом предударном слоге, свойственное всем белорусским - а также многим русским, в том числе псковским - диалектам и регулярно фиксируемое памятниками с XV века [КАРскій 1908: 202-203].

4 Датирующие признаки: ж III “звездоподобные в 4 взмаха” (до [1320], предпочтительно до [1220]), o 4 “вместо правой дуги прямая” (после [1300]), $p \mathrm{~V}$ “петля с двумя изломами” (после [1280]). Буква $p$ в надписи имеет необычное начертание с сильно выгнутой мачтой (особенно $p$ в первой строке).

5 Слово ищазаєть в Псалтыри 1296 года (ГИМ, Син., 235) обыкновенно трактуется как форма старославянского глагола ищазати, а не как случай отражения яканья. 
В надписи использована довольно редкая формула, ср. два ранних

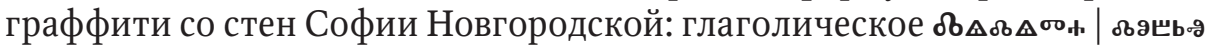

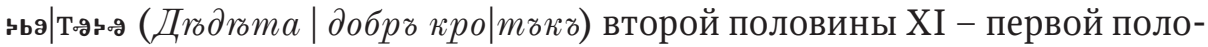
вины XII века (вероятно, не позже начала XII века) [Михевв 2012: 7980, № 16] и кириллическое Hacm [a] правzдzн[б] | добрг ... (дальнейший текст читается неудовлетворительно) второй половины XI - начала XII века ${ }^{6}$. Смысл данный формулы, вероятно, заключается в том, что пишущий выражает при помощи нее благодарность своему благодетелю, в рассматриваемом случае - Марковой жене ${ }^{7}$.

Имя Маржг (или $М а р к о)^{8}$ представлено еще как минимум один раз в эпиграфике Спасо-Преображенской церкви - в надписи второй половины XII - XIII века $\vec{\Gamma}$ помози рабоу своемоу $\mid$ Ma $a^{{ }_{\text {r }}}$ кови на мног $[a] л[r m](a)^{9}$.

\section{"Ежков нож" из Дрогичина Надбужкского}

Надпись публикуется благодаря Дариушу Домбровскому, отыскавшему несущий ее артефакт в Государственном археологическом музее в Варшаве, а также археологам Анджею Пётровскому и Сильвии Вайде, организовавшим и произведшим его цифровую фотосъемку (серия высококачественных цифровых фотографий этой находки была выполнена С. Вайдой весной 2014 года).

Место хранения: Варшава, Государственный археологический музей (Państwowe Muzeum Archeologiczne), инвентарный № PMA V/1454.

Место и условия находки: По музейным сведениям, артефакт происходит из раскопок К. Мусянович, производившихся в июле 1954 года на раскопе I на западном посаде Дрохичина (древнерусского Дорогичина) в Семятыченском повете Подляшского воеводства Польши. Дрохичин / Дрогичин / Дорогичин находится примерно в 100 км на северо-запад от Бреста (древнерусского Берестья), ниже по течению Западного Буга, на правом берегу реки ${ }^{10}$. В древнерусский период он был пограничным

6 Надпись Насты пока не опубликована, она находится на восточной грани южной лопатки юго-восточного подкупольного столба, в дьяконнике, в 5 см от левого края и 18 см ниже современного пола.

7 Следует рассмотреть и возможность того, что Маркова жена оставила данную надпись сама. Вероятность этого крайне мала, так как граффито располагается в алтарной части церкви, куда доступ женщинам воспрещен. Начертав здесь восхваляющую ее надпись, Маркова жена совершила бы два греха одновременно.

8 Добавлю, что наличие между слогами словоформы Марғжова вставного ъ типично и для раннедревнерусского и для более позднего времени.

9 Конец надписи, к сожалению, плохо видный на фотографии, прочтен ее издателем как на много лет (z). И. З. Залилов датировал данную надпись XIII веком [ЗАлилов 2014: 81-82, табл. LIII: 3-4, № 88].

10 Не путать с другим Дрогичином - районным центром Брестской области Белоруссии, который находится в 100 км к востоку от Бреста. 
городом и служил местом взимания таможенных пошлин. По сообщению К. Мусянович, артефакт был найден на участке А раскопа I, недалеко от границы с участком В, в квадрате 88, на глубине 1,5 м [MUSIANOWICZ 1955: 343].

Эпиграфическое поле: Костяная рукоять ножа. Материал: одно из средних ребер зубра (по определению К. Крысяка) [MuSIANOWICZ 1955: 343; РорРе 1957: 90] ${ }^{11}$. Одна из плоских сторон рукояти сохранилась почти целиком, другая же почти полностью отколота. Размеры: длина 12,3 см, ширина 3,8 см. К. Мусянович полагала, что такие крупные размеры могли быть только у боевого ножа [MUSIANOWICZ 1955: 343] (со ссылкой на работу [Колчин 1953: 72]). Между тем, согласно А. Н. Кирпичникову, “воинские ножи в большинстве случаев не отличаются от обычных бытовых. И те и другие были разного размера [. . .] Для воина нож являлся универсальным хозяйственным и походным инструментом” [Кирпичников 1966: 72], следовательно нет никаких оснований считать нож, рукоять которого была найдена К. Мусянович, боевым ${ }^{12}$.

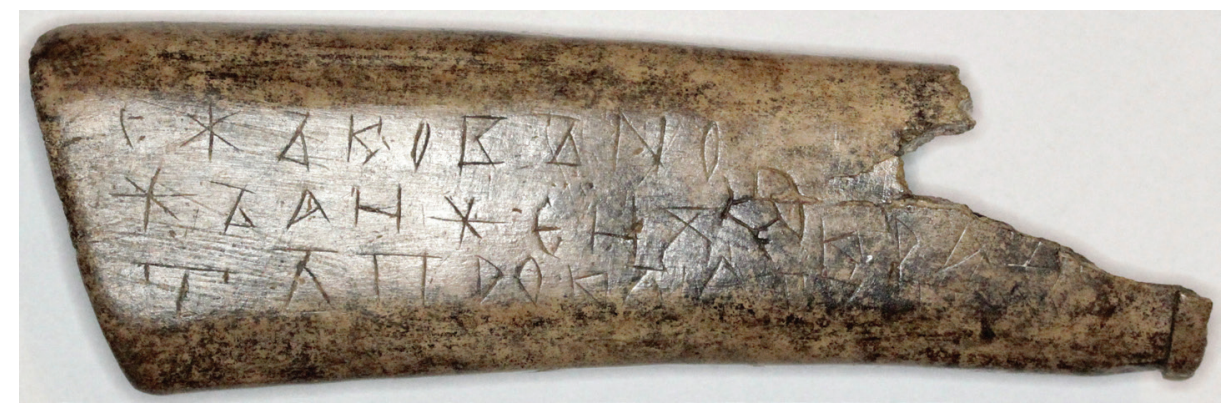

Рис. 3. Рукоять ножа. Фотография С. Вайды

Fig. 3. Knife handle. Photograph by S. Wajda

Тип надписи: Граффито.

Сохранность: Обломом рукояти частично уничтожены две последние буквы второй строки. Нижние части букв третьей строки, по-видимому, стерты в древности при использовании рукояти.

11 В. В. Немчук также не исключает того, что рукоять была вырезана из лопатки лося.

12 Ср. также соображения А. Поппэ: [PоPPE 1957: 91]. 

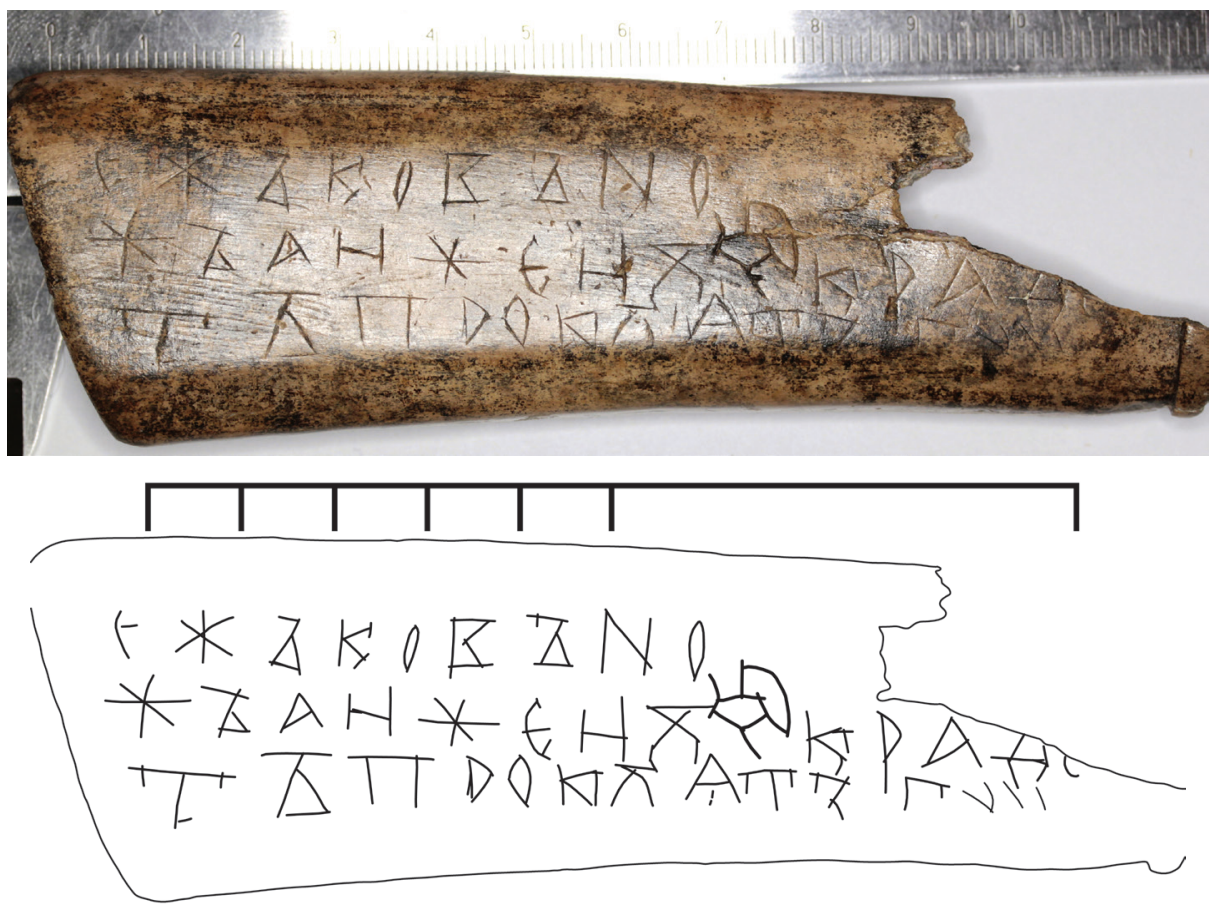

Pис. 4. Надпись на рукояти ножа. Фотография С. Вайды, прорись автора

Fig. 4. Inscription on the knife handle. Photograph by S. Wajda, line drawing of the author

\section{Текст:}
1 Ежьковъ но=
2 жь а иже и жкраде=
3 ть проклать -

Лингвистический разбор:

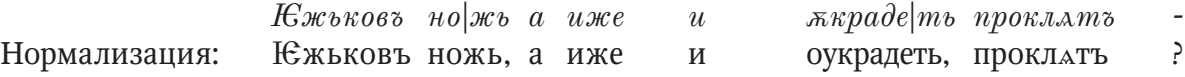

Грамм. характ-ка: NOM.SG.M NOM.SG NOM.SG.M ACC.SG.M PRES.3.SG T-PART.NOM.SG.M

Словарная форма: Южьковъ ножь а иже ${ }^{*}$ и оукрасти проклАти

Перевод: 'Ежков нож. А кто его украдет, проклят ...'.

Издания: (фотография, прорись) Musianowicz 1955: 343-344, tabl. XLVI'13; (фотографии, прориси) РорРе 1957.

Литература: КАЛЕчЫЦ 2011: 99, 207 (рыс. 77); НІмчук 2013; КОВАЛЬ, МЕДЫНЦЕВА 2013: $169^{14}$.

13 К. Мусянович ссылается на помощь А. Мировича в прочтении текста надписи.

14 Мне, к сожалению, пока недоступны следующие работы, в которых, судя по всему, идет речь о рассматриваемой надписи: это книги Ю. И. Гаврилюка 
Датировка: К. Мусянович не указала датировок слоя, в котором была найдена рукоять. По ее данным, изученная в 1954 году часть поселения существовала с конца XI или начала XII по начало или первую половину XIII века [MUSIANOWICZ 1955: 344-345]. Это обстоятельство вкупе с полным отсутствием инновационных черт в палеографии надписи позволяют датировать граффито концом XI - XII веком, предпочтительно концом XI - началом XII века ${ }^{15}$.

Комментарий: Надпись почти полностью занимает одну из плоских сторон рукояти. До надписи и другим - более толстым - инструментом здесь был вырезан рисунок или знак (возможно, тамга), находящийся между буквами жи и $\kappa$ второй строки надписи ${ }^{16}$. Писавший перешел с первой строки на вторую, упершись в это изображение, а дойдя до рисунка во второй строке, сделал отступ перед буквой $\kappa$.

После завершающей третью строку буквы (б с затертой петлей или 2) видны еще четыре тонких штриха. Все исследователи надписи ошибочно интерпретировали данные штрихи как буквенные ${ }^{17}$. Места для продолжения текста в этой строке не было. Возможно, дополнительные тонкие штрихи имели орнаментальное назначение. Уверенно определить, принадлежат ли они руке автора надписи, не представляется возможным. Таким образом, последнее слово надписи, скорее всего, было

“Історія Підляшшя (Берестейської землі) у X-XIV століттях" (Гайнівка, 1990) и "Podlasze: Śladami ruskiej przeszłości” (Bielsk Podlaski, 2000) и книга К. Мусянович "Drohiczyn od VI do XIII wieku: dzieje i kultura" (Olsztyn; Białystok, 1982).

15 В надписи представлено архаичное начертание буквы ж типа Іа “ “прямая звезда" по А. А. ЗАлизняку [2000: 164-166, 222]. Концом XI - началом XII века граффито датировали также И. Л. Калечиц и В. В. Немчук, между тем как А. Поппэ относил надпись к памятникам XII века.

${ }_{16}$ По мнению А. Поппэ, это мог быть знак, изображающий птицу [РорРе 1957: 90].

17 Были предложены следующие интерпретации текста после слова проклАтг: $\sigma-\mu$, то есть ‘богом’ (К. Мусянович; А. Поппэ); пять нечитаемых букв (sic!) с предположительным переводом ‘будет / пойдет?’ (И. Л. Калечиц); гдм, то есть господгмь (В. В. Немчук). Следует указать на еще несколько ошибок в предлагавшихся ранее вариантах прочтения надписи Ежка. А. Поппэ писал, что $m ь$ в начале третьей строки - это местоимение, хотя перед нами окончание глагольной словоформы. И. Л. Калечиц, не знакомая с публикацией А. Поппэ, ошибочно относит надпись Ежка к одноеровым. Между тем у этимологических ерей в данном граффито нет засечек слева, но есть широкие горизонтальные полузасечки-полупокрытия, уходящие в двух случаях правее мачты буквы, а у конечных еров в словах Ежьковъ и проклатъ на фотографиях хорошо видны вертикальные засечки слева, следовательно, эти буквы являются ерами, а остальные - ерями (не расположение горизонтального элемента относительно мачты, а именно наличие или отсутствие вертикальной засечки является в подобных случаях смыслоразличительным, как, например, в новгородских берестяных грамотах № 718 и 742). В. В. Немчук, не знакомый с публикациями К. Мусянович и И. Л. Калечиц, вслед за А. Поппэ не исключает ошибочного чтения 8 для буквы $\pi$ во второй строке, полагая возможным наличие покрытия у буквы 8 (sic!), как у буквы $л$ в третьей строке. 
не дописано. Наиболее вероятно, что Ежко хотел употребить здесь слово блдеть “будет”'18.

Почерк надписи очень значительно различается в первой и последующих строках. Первая строка написана аккуратным и весьма стандартным почерком, а вторая и третья строки выглядят совершенно иначе: все буквы размашисты и ярко индивидуальны, засечки непропорционально длинны. Наибольшие отличия между двумя манерами письма заметны в начерках букв $x$ и ж, представленных в обеих частях граффито. Пример подобной смены почерка с красивого официального в первой строке надписи на неупорядоченный, но более оригинальный и запоминающийся находим в автографе писца Мутижира Огафангеловича второй половины XI - начала XII века на стене Софии Новгородской [ГипПиУс, МихеЕв 2013: 161-162].

Кроме общей размашистости и не вполне обычного начертания ж в виде горизонтально перечеркнутой буквы $x$ почерк второй и третьей строк надписи Ежка выделяется использованием нестандартного варианта большого юса, который не имеет нижнего короткого вертикального штриха, то есть является “полым юсом большим” по терминологии А. А. Зализняка ${ }^{19}$.

Притяжательная форма Ежьюовг не позволяет уверенно утверждать, звучало ли имя владельца ножа как *Ежько или как *Ежькъ. Вариант *Ежько находит себе подтверждение в прозвище крестьянина Турского погоста Новгородского уезда Никитки Вожка [Тупиковъ 1903] ${ }^{20}$. Ср. также [Німчук 2013: 141].

Особенности графической системы и языка надписи позволяют констатировать, что надпись написана либо на наддиалектном древнерусском языке, либо на диалекте, отличавшемся от него не очень значительно (например, на местном диалекте Берестейской земли) ${ }^{21}$. В граффито

18 Благодарю А. А. Гиппиуса за консультацию по этому вопросу. Ср. многочисленные примеры заклятий с использованием слова прокллтг [СДРЯ, 9: 84-86]. Впрочем, нельзя полностью исключать возможности интерпретировать последнюю букву надписи как цифру · $\overrightarrow{2} \cdot$ '3' (отсутствие глагола-связки в таком случае можно объяснить презентной семантикой: ‘А кто его украдет, тот трижды проклят').

19 Рядом с буквой . в в третьей строке видно несколько тонких вертикальных царапин, одна из которых находится под большим юсом второй строки, однако эти царапины не являются частью надписи. “Полый юс большой” представлен в трех новгородских берестяных грамотах: № 903 рубежа XI-XII веков, № 778 начала XIII века (грамота представляет собой азбуку, где “полый юс большой” следует за обыкновенным юсом большим) и № 151 второй четверти XIII века. Подробнее см. [ЗАлизняк 2000: 212 (табл. 36)] (в таблице здесь ошибочно указан № 904 вместо № 903) и [Янин, ЗАлизняк 2004: 15-16, 95].

20 Ср. другие варианты антропонимов от того же корня: Вожикг, Вожевг, Ежевг [Тупиковъ 1903].

21 В. В. Немчук в своей статье “Давньоукраїнський напис із Дорогичина” охарактеризовал рассматриваемое граффито как “один из древнейших 
представлены восточнославянское смешение ж и у (жкрадеть); употребление $e$-, а не $o^{-}$, свойственного основной части будущего белорусского ареала, в корне *jež- (Ежьково) ${ }^{22}$; употребление -ms, а не -mъ и не нулевого окончания, в 3-м лице презенса (жкрадеть).

\section{Библиограсрия}

Гиппиус, Михевв 2013

Гиппиус А. А., МихеЕв С. М., “О подготовке Свода надписей-граффити Новгородского Софийского собора”, в: А. М. МолдовАн, отв. ред., Письменность, литература, фольклор славянских народов. История славистики: ХV Международный съезд славистов. Минск, 20-27 августа 2013 г.: Доклады российской делегации, Москва, 2013, 152-179.

ЗАлизняк 2000 ЗАлизняк А. А., “Палеография берестяных грамот и их внестратиграфическое датирование”, в: В. Л. Янин, А. А. ЗАлизняк, Новгородские грамоты на бересте, 10: (Из раскопок 1990-1996 г2.). Палеография берестяных грамот и их внестратиграфическое датирование, Москва, 2000, 134-429.

ЗАлилов 2014

ЗАлилов И. З., Граффити Спасо-Преображенской церкви в Полоцке XII-XVII вв., Полоцк, 2014.

КАЛЕЧИЦ 2013

КАЛЕчИЦ И. Л., “Антропонимия алтарных граффити Спасо-Преображенской церкви города Полоцка”, Вопросы эпиграфики, 7: Материалы I Международной конференции “Вопросы эпиграфики”, 2, Москва, 2013, 135-145.

КАЛЕЧЫЦ 2011

КАЛЕчЫЦ І. Л., Эпіграфіка Беларусі X-XIV стст., Мінск, 2011.

КАРСКІЙ 1908

КАРскій Е. Ө., Бплоруссы, 2: Языкъ бплорусскаго племени, 1: Историческій очеркъ звуковъ бълорусскаго нарпчія, Варшава, 1908.

Кирпичников 1966

Кирпичников А. Н., Древнерусское оружие, 1: Мечи и сабли IX-XIII вв. (= Археология СССР: Свод археологических источников, Е1-36), Москва, Ленинград, 1966.

КовАЛЬ, МЕДЫНцЕвА 2013

КовАЛЬ В. Ю., МЕдынцевА А. А., “Новая эпиграфическая находка домонгольской эпохи с городища Ростиславль”, Вопросы эпиграфики, 7: Материалы I Международной конференции “Вопросы эпиграфики”, 2, 2013, 164-174.

Колчин 1953

Колчин Б. А., Черная металлургия и металлообработка в Древней Руси (домонгольский период) (= Материалы и исследования по археологии СССР, 32), Москва, 1953.

МЕДЫНЦЕвА 1978

Медынцева А. А., Древнерусские надписи новгородского Софийского собора: XI-XIV века, Москва, 1978.

памятников живого языка украинских полещуков” [НІмчук 2013: 141]. Между тем называть этот древний диалект украинским или белорусским не вполне корректно.

22 Следует отметить, что зона рефлексов * ožь обходит стороной западнополесский регион [ОЛА 2011: карта 1]. Ср. также [ОЛА 2011: карты 2-6]. Благодарю М. Н. Толстую и С. Л. Николаева за консультацию по этому вопросу. 
МихеЕв 2012

МихеЕв С. М., “22 древнерусских глаголических надписи-граффити XI-XII веков из Новгорода”, Slovo: Časopis Staroslavenskoga instituta u Zagrebu, 62, 2012, 63-99.

НІмчук 2013

НІмчук В. В., “Давньоукраїнський напис із Дорогичина”, в: Храм і люди: Збірка статей до 90-річчя з дня народження Сергія Олександровича Висоцького, Київ, 2013, 138-142.

ОЛА 2011

Общеславянский лингвистический атлас (ОЛА), Серия фонетико-грамматическая, 6: Рефлексы ${ }^{*}$, Москва, 2011.

САРАБЬЯНОВ 2012

САРАБьянов В. Д., “Живопись середины 1120-х - начала 1160-х годов”, в: История русского искусства, 2/1: Искусство 20-60-х годов ХІІ века, Москва, 2012, 158-335.

СДРЯ, 9

Словарь древнерусского языка (XI-XIV вв.), 9: провадити - ражьзизаюми, Москва, 2012.

Тупиковъ 1903

Тупиковъ Н. М., Словарь древне-русскихъ личныхъ собственныхъ именъ, С.-Петербургъ, 1903.

Янин, ЗАлизняк 2004

Янин В. Л., ЗАлизняк А. А., “Новгородские грамоты на бересте: [№№] 776-915 (из раскопок 1997-2000 гг.)”, в: В. Л. Янин, А. А. ЗАлизняк, А. А. Гиппиус, Новгородские грамоты на бересте, 11: Из раскопок 1997-2000 г2., Москва, 2004, 9-107.

Musianowicz 1955

Musianowicz K., "Sprawozdanie z prac wykopaliskowych przeprowadzonych w roku $1954 \mathrm{w}$ Drohiczynie, pow. Siemiatycze," Wiadomości archeologiczne. Bulletin archéologique Polonais, 12/3-4, 1955, 332-346.

Poppe 1957

PopPe A., "Zabytek epigrafiki staroruskiej z Drohiczyna: Napis na rękojeści noża z XII wieku," Studia źródtoznawcze: Commentationes, 1, 1957, 89-108.

\section{References}

Gippius A. A., Mikheev S. M., “O podgotovke Svoda nadpisei-graffiti Novgorodskogo Sofiiskogo sobora," in: A. M. Moldovan, ed., Pis'mennost', literatura, fol'klor slavianskikh narodov. Istoriia slavistiki: XV Mezhdunarodnyi s"ezd slavistov. Minsk, 20-27 avgusta 2013 g.: Doklady rossiiskoi delegatsii, Moscow, 2013, 152-179.

Kalechyts I. L., Epihrafika Belarusi X-XIV stst. Minsk, 2011.

Kalechyts I. L., "Antroponimiia altarnykh graffiti Spaso-Preobrazhenskoi tserkvi goroda Polotska," Voprosy epigrafiki, 7/2, Moscow, 2013, 135-145.

Kirpichnikov A. N., Drevnerusskoe oruzhie, 1: Mechi i sabli IX-XIII vv., Moscow, Leningrad, 1966.

Kolchin B. A., Chernaia metallurgiia i metalloobrabotkav Drevnei Rusi (domongol'skii period), Moscow, 1953.

Koval' V. Yu., Medyntseva A. A., "Novaia epigraficheskaia nakhodka domongol'skoi epokhi s gorodishcha Rostislavl'," Voprosy epigrafiki, 7/2, Moscow, 2013, 164-174.
Medyntseva A. A., Drevnerusskie nadpisi novgorodskogo Sofiiskogo sobora: XI-XIV veka, Moscow, 1978.

Mikheev S. M., "22 drevnerusskikh glagolicheskikh nadpisi-graffiti XI-XII vekov iz Novgoroda," Slovo: Časopis Staroslavenskoga instituta u Zagrebu, 62, 2012, 63-99.

Musianowicz K., "Sprawozdanie z prac wykopaliskowych przeprowadzonych w roku 1954 w Drohiczynie, pow. Siemiatycze," Wiadomości archeologiczne. Bulletin archéologique Polonais, 12/3-4, 1955, 332-346.

Nimchuk V. V., "Davn'oukrains'kyi napys iz Dorohychyna," in: Khram i liudy: Zbirka statei do 90-richchia z dnia narodzhennia Serhiia Oleksandrovycha Vysots'koho, Kiev, 2013, 138-142.

Poppe A., "Zabytek epigrafiki staroruskiej z Drohiczyna: Napis na rękojeści noża z XII wieku," Studia źródtoznawcze: Commentationes, 1, 1957, 89-108.

Sarabyanov V. D., 'Zhivopis' serediny 1120kh - nachala 1160-kh godov," in: Istoriia russkogo 
iskusstva, 2/1: Iskusstvo 20-60-kh godov XII veka, Moscow, 2012, 158-335.

Yanin V. L., Zalizniak A. A., "Novgorodskie gramoty na bereste: 776-915 (iz raskopok 19972000 gg.)," in: V. L. Yanin, A. A. Zalizniak, A. A. Gippius, Novgorodskie gramoty na bereste, 11, Moscow, 2004, 9-107.
Zalilov I. Z., Graffiti Spaso-Preobrazhenskoi tserkvi v Polotske XII-XVII vv., Polotsk, 2014.

Zalizniak A. A., "Paleografiia berestianykh gramot i ikh vnestratigraficheskoe datirovanie," in: V. L. Yanin, A. A. Zalizniak, Novgorodskie gramoty na bereste, 10, Moscow, 2000, 134-429.

Савва Михайдович Михеев, канд. ист. наук

Институт славяноведения РАН, старший научный сотрудник Отдела типологии и сравнительного языкознания

119991, Москва, Ленинский проспект, 32А

Россия/Russia

mikheev@gmail.com 